\title{
PERBEDAAN KADAR HEMOGLOBIN DAN PARAMETER ERITROSIT PADA PENDERITA PENYAKIT PARU OBSTRUKTIF KRONIK POPULASI D YANG TIDAK DAN YANG MENDAPAT TERAPI INHALASI KOMBINASI LONG ACTING B2 AGONIST-KORTIKOSTEROID
}

\author{
Triwahju Astuti ${ }^{\star 凶}$, Karima $^{* *}$, Agustin Iskandar ${ }^{\star * *}$
}

\begin{abstract}
Abstrak
Penyakit Paru Obstruktif Kronik (PPOK) merupakan penyakit paru yang didasari salah satunya oleh reaksi inflamasi yang meningkat sehingga menimbulkan hambatan aliran udara dan perusakan pada eritrosit, sehingga terjadi resistensi hormon eritropoietin. Populasi D merupakan pasien PPOK yang memiliki risiko eksaserbasi tertinggi dan gejala yang paling berat di antara populasi lainnya. Terapi lini pertama untuk pasien PPOK populasi D yang direkomendasikan GOLD adalah terapi LABACS (long acting beta2 agonist and corticosteroid). Penelitian ini dilakukan untuk mengetahui perbedaan kadar hemoglobin dan parameter eritrosit berupa jumlah eritrosit, nilai red blod cell distribution width dan indeks eritrosit penderita PPOK populasi $D$ yang mendapat dan tidak mendapat LABACS. Penelitian ini menggunakan metode observational cross sectional dengan melihat rekam medis pasien PPOK pada bulan Juni sampai November 2015. Hasilnya pada terapi LABACS didapatkan kadar hemoglobin yang lebih tinggi dibandingkan dengan tanpa terapi, jumlah eritrosit, nilai $\mathrm{MCV}, \mathrm{MCH}, \mathrm{MCHC}$ lebih rendah dibandingkan dengan tanpa terapi, dan nilai RDW lebih tinggi dibandingkan dengan tanpa terapi LABACS. Selain itu, persentase pasien PPOK yang terkena anemia pada kelompok yang mendapat terapi LABACS lebih rendah dibanding dengan yang tidak mendapat terapi. Kadar hemoglobin, jumlah eritrosit, indeks eritrosit, dan RDW dievaluasi dengan program SPSS 16.0. Tidak didapatkan perbedaan yang signifikan pada semua parameter. Kesimpulannya, tidak terdapat perbedaan kadar hemogolobin dan parameter eritrosit antara pasien PPOK populasi D yang mendapat dan tidak mendapatkan terapi LABACS.
\end{abstract}

Kata kunci: eritrosit, hemoglobin, LABACS, penyakit paru obstruktif kronik, red blood cell distribution width.

\section{THE DIFFERENCES OF HEMOGLOBIN LEVELS AND ERYTHROCYTE PARAMETERS IN CHRONIC OBSTRUCTIVE PULMONARY DISEASE PATIENTS POPULATION D WITH AND WITHOUT ICS/LABA THERAPY}

\footnotetext{
Abstract

Chronic Obstructive Pulmonary Disease is a multifactorial disease, one of the processes is based on increased inflammatory reaction that makes persistent airflow limitation and erythrocyte damage that is related to erythropoietin resistance. Population D is COPD patients who have the highest risk of exacerbations and the most severe symptoms among other populations. Firstline treatment recommended by guideline GOLD for COPD population D patients is ICS/LABA combination. This experiment is aimed to know the differences in hemoglobin levels, total erythrocyte, erythrocyte indices, and RDW in COPD patients population $D$ that using and not using ICS/LABA therapy. This experiment was using an observational crosssectional method by looking at the COPD patients' medical records from June until November of 2015. The result in LABACS therapy found higher hemoglobin levels compared with no treatment, erythrocyte count, $\mathrm{MCV}, \mathrm{MCH}, \mathrm{MCHC}$ values were lower than without therapy, and RDW values were higher than those without LABACS therapy. Hemoglobin levels, total erythrocyte, erythrocyte indices, and RDW values are evaluated with SPSS 16.0. There is no significant difference in all parameters. In conclusion, there are no differences in hemoglobin levels and erythrocyte parameters between COPD population D patients with and without LABACS medications.

Keywords: chronic obstructive pulmonary disease, erythrocyte, hemoglobin, LABACS, red blood cell distribution width.

*Departemen Pulmonologi dan Kedokteran Respirasi, Fakultas Kedokteran, Universitas Brawijaya

**Program Studi Kedokteran, Fakultas Kedokteran, Universitas Brawijaya

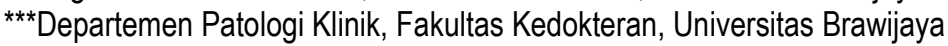

E-mail: astuti@ub.ac.id
} 


\section{Pendahuluan}

Penyakit Paru Obstruktif Kronik (PPOK) merupakan penyakit kronik yang ditandai oleh gejala respiratorik persisten dan hambatan aliran udara di saluran napas serta hasil pemeriksaan spirometri menunjukkan FEV1/ FVC kurang dari 0.70. Di Indonesia, PPOK menjadi penyakit yang menyebabkan kematian terbanyak di peringkat ke-6 dari 10 . Data terbaru menurut Riset Kesehatan Dasar 2013, prevalensi PPOK di Indonesia saat ini sebesar 3,7\%.1,2 WHO juga memperkirakan kasus PPOK akan cenderung meningkat dari tahun ke tahun, bahkan pada 2020 menjadi penyebab kematian ke-3 tertinggi di dunia. ${ }^{3}$

Pasien PPOK menurut guideline GOLD dibagi menjadi 4 populasi, yaitu populasi $A, B$, $C$, dan D. Penilaian gabungan untuk menentukan keparahan penyakit PPOK dibagi berdasarkan asesmen hambatan aliran udara, risiko eksaserbasi, dan gejala yang muncul. Populasi $\mathrm{D}$ berdasarkan asesmen hambatan aliran udaranya maka hasil uji spirometri termasuk GOLD 3 (FEV1 30-50\%) atau GOLD 4 (FEV1 < 30\%). Berdasarkan risiko eksaserbasi, maka pasien pasien PPOK dikatakan populasi $\mathrm{D}$ bila memiliki riwayat eksaserbasi $\geq 2$ dalam 12 bulan atau $\geq 12$ bulan dirawat di rumah sakit. Terakhir bila dilihat dari asesmen gejala yang muncul, populasi $D$ merupakan kelompok pasien yang gejalanya berat ditandai dengan hasil CAT $\geq 10$ atau $\mathrm{mMRC} \geq 2$. Berdasarkan pembagian di guideline GOLD maka populasi $D$ menjadi populasi pasien PPOK yang paling berat karena berisiko tinggi dan gejala yang muncul lebih banyak. ${ }^{4}$

Menurut guideline GOLD 2016, terapi kombinasi long acting beta 2 agonist and corticosteroid (LABACS) dijadikan sebagai lini pertama untuk populasi D penderita PPOK karena mengurangi kejadian eksaserbasi dibanding pasien yang mendapat plasebo. ${ }^{5}$ Obat golongan beta2 agonist bekerja dengan cara merelaksasi otot polos di saluran nafas, meningkatkan klirens mukosilier, mengurangi permeabilitas vaskuler dan mengatur pelepasan mediator dari sel mast dan basofil untuk mengontrol bronkokonstriksi episodik. Kortikosteroid dengan durasi kerja 4-6 jam dapat mengurangi produksi sitokin proinflamasi pada pasien PPOK stabil. ${ }^{5}$ Kortikosteroid juga mengobati eksaserbasi akut yang berat karena dapat mencegah memburuknya eksaserbasi dalam onset cepat, menurunkan angka masuk UGD atau rumah sakit, mencegah relaps setelah kunjungan ke UGD dan menurunkan morbiditas. ${ }^{6}$

Hemoglobin merupakan protein kompleks di dalam eritrosit yang berguna untuk membawa oksigen dan karbon dioksida di dalam sirkulasi. ${ }^{7}$ Pada pasien PPOK populasi $D$ yang sudah mengalami hipoksemia berkepanjangan, maka tubuh akan mengkompensasi dengan meningkatkan produksi eritrosit melalui stimulasi hormon eritropoeitin. Namun di sisi lain, juga dapat ditemukan pasien dengan anemia diakibatkan respons inflamasi meningkatkan kadar sitokin proinflamasi (IL-6, TNF a, IFN y) sehingga menurunkan masa hidup eritrosit. Pada saat ini, lebih banyak ditemukan pasien dengan penurunan hemoglobin (anemia) dibandingkan peningkatan hemoglobin (polisitemia) akibat penggunaan Long Therm Oxygen Theraphy (LTOT). Anemia lebih banyak dilaporkan sebagai komorbiditas pada PPOK dan dapat menurunkan kualitas hidup dan angka survival pasien. ${ }^{8}$

Pemeriksaan Red Cell Distribution Width (RDW) bisa dilakukan untuk mengetahui heteregonitas ukuran eritrosit dan melihat tipe klinis anemia. Menurut beberapa studi sebelumnya, terdapat hubungan antara kadar RDW yang tinggi dengan peningkatan mortalitas beberapa penyakit termasuk PPOK. ${ }^{9}$ 
Pemeriksaan lainnya yang bisa dilakukan untuk mengetahui jenis kelainan eritrosit adalah indeks eritrosit yang terdiri dari Mean Corpuscular Volume (MCV), Mean Corpuscular Hemoglobin (MCH), dan Mean Corpuscular Hemoglobin Concentration (MCHC).

Berdasarkan acuan di GOLD 2016, pasien populasi $D$ dengan risiko tinggi eksaserbasi direkomendasikan menggunakan LABACS atau kombinasi antara long acting beta2 agonist dengan Kortikosteroid, sehingga dari latar belakang tersebut peneliti bermaksud untuk mengetahui apakah terdapat perbedaan kadar hemoglobin dan parameter eritrosit pada penderita PPOK populasi D yang mendapatkan terapi LABACS dan tidak mendapat terapi LABACS. Parameter eritrosit dilihat dari jumlah eritrosit, nilai Red Blood Cell Distribution Width, dan indeks eritrosit pada penderita PPOK populasi D.

\section{Bahan dan Metode}

Penelitian ini merupakan studi cross sectional yang dilakukan mulai bulan Juni hingga November 2015. Pasien PPOK yang datang ke poliklinik Paru RS. Dr. Saiful Anwar Malang dilakukan screening oleh PPDS atau Dokter Spesialis Paru. Lalu, pasien dikelompokkan dengan menggunakan COPD Assesment Test (CAT) dan dipilih sesuai kriteria inklusi yaitu pasien sudah mendapat terapi LABACS $\geq 6$ bulan, laki-laki, usia $40-80$ tahun, riwayat merokok, dan dalam kondisi stabil (tidak ada eksaserbasi dalam 2 minggu). Setelah itu, data pasien yang dibutuhkan diambil dari rekam medis pasien, yaitu kadar hemoglobin, jumlah eritrosit, nilai indeks eritrosit, dan Red Blood Cell Distribution Width.

\section{Pemeriksaan Laboratorium Lengkap}

Tes darah lengkap dilakukan antara bulan Juni-November 2015 dan dievaluasi.

\section{Pengolahan dan Analisis Data}

Data penelitian yang sudah terkumpul dilakukan cleaning, coding, dan tabulasi. Pengolahan dan analisis data dilakukan secara manual dan komputerisasi dengan menggunakan SPSS (Statistical Package for the Social Sciences) 16.0 for Windows dengan tingkat signifikansi atau nilai probabilitas $0,05(p=0,05)$ dan taraf kepercayaan $95 \%(\alpha=0,05)$. Langkah uji hipotesis yang dilakukan adalah uji normalias, uji homogenitas data, dan uji parameterik T-test independent.

\section{Hasil}

Jumlah pasien yang mengikuti penelitian masing-masing kelompok 17 orang yang mendapatkan LABACS dan tidak mendapatkan LABACS, semua pasien berjenis kelamin laki-laki, usia 40-80 tahun, dan tidak mengalami eksaserbasi selama minimal 2 minggu, dan memiliki riwayat merokok atau perokok. Analisis data dilakukan setelah mengambil data pemeriksaan darah lengkap yang didapatkan dari rekam medis pasien PPOK populasi $D$ yang sudah mendapat terapi LABACS lebih dari 6 bulan dan kelompok pasien yang tidak mendapatkan terapi LABACS di RS. Dr. Saiful Anwar. Pada Tabel 1, diketahui rerata usia pasien pada kelompok LABACS dan non LABACS 66,5 tahun dan 65,6 tahun, sedangkan rata-rata BMI 20,85 kg/m2 dan 20,77 $\mathrm{kg} / \mathrm{m}^{2}$. Pada Tabel 1, diketahui rerata usia pasien pada kelompok LABACS dan non LABACS 66,5 tahun dan 65,6 tahun, sedangkan rata-rata BMI 20,85 kg/m2 dan 20,77 $\mathrm{kg} / \mathrm{m}^{2}$. Dari hasil pemeriksaan tersebut didapatkan penurunan FEV1 pada kedua kelompok yang menandakan adanya obstruksi di saluran napas, hal ini semakin didukung dengan hasil FEV1/FVC $<70 \%$ yang menandakan bahwa pasien terkena Penyakit Paru Obstruktif Kronik. 
Pada pemeriksaan hitung darah lengkap, rata-rata kadar hemoglobin pasien yang mendapat LABACS dan non LABACS $14,6 \mathrm{~g} / \mathrm{dL}$ dan $14,5 \mathrm{~g} / \mathrm{dL}$, jumlah eritrosit $5,14 \times 10^{6}$ dan $5,23 \times 10^{6}$, MCV 84,08 fl dan $85,35 \mathrm{fl}, \mathrm{MCHC} 33,82 \mathrm{~g} / \mathrm{dL}$ dan $34,19 \mathrm{~g} / \mathrm{dL}$, MCH 28,5 pg dan 28,7 pg, serta nilai RDW $13,84 \%$ dan $13,82 \%$. Dari hasil data penelitian juga ditemukan terdapat 2 dari 17 pasien $(11,7 \%)$ dengan anemia pada kelompok LABACS, dan 4 dari 17 pasien $(23,5 \%)$ dari kelompok non LABACS dengan anemia.

Pada Tabel 2 terlihat bahwa tidak didapatkan perbedaan yang bermakna rerata kadar hemoglobin pada pasien PPOK yang tidak mendapat dan yang mendapat terapi LABACS. Pasien PPOK yang mendapat terapi LABACS terdapat kecenderungan peningkatan rerata kadar hemoglobin dibanding pasien yang tidak mendapatkan LABACS. Hal ini didukung dengan prevalensi anemia yang ditemukan pada pasien non LABACS sebesar $29,4 \%$, sedangkan pada pasien yang mendapatkan LABACS hanya $5,8 \%$. Namun, pada perhitungan jumlah eritrosit, pasien LABACS memiliki rerata jumlah eritrosit yang lebih rendah dibandingkan pada pasien yang tidak mendapatkan terapi LABACS. Begitu pula hasil dari rata-rata MCV, MCHC, dan $\mathrm{MCH}$ terdapat tren penurunan pada pasien yang mendapat terapi LABACS dibanding kelompok non LABACS. Namun, rata-rata RDW pasien yang mendapat terapi LABACS terdapat kecenderungan penurunan yang menandakan tingkat inflamasi yang tidak jauh berbeda pada dua kelompok tersebut. Dari hasil rata-rata dapat diartikan bahwa ukuran eritrosit lebih kecil, konsentrasi hemoglobin lebih sedikit, dan massa hemoglobin yang lebih rendah pada pada pasien yang mendapat LABACS namun masih dalam batas normal dibandingkan dengan pasien yang tidak mendapat terapi LABACS.

Tabel 1. Demografik dan karakteristik kelompok LABACS dan non LABACS.

\begin{tabular}{lcc}
\hline & LABACS $(\mathrm{n}=17)$ & Non LABACS $(\mathrm{n}=17)$ \\
\hline Umur (tahun) & 66,5 & 65,6 \\
BMI (kg/m²) & 20,85 & 20,77 \\
FVC (\%) & 71,87 & 69,82 \\
FEV1 (\%) & 47,01 & 45,4 \\
FEV1/FVC (\%) & 51,62 & 51,12 \\
Jumlah rokok/hari & 16,3 & 19,6 \\
Lama merokok (thn) & 33,4 & 35,6 \\
Pack per year & 27,6 & 37,5 \\
Hemoglobin (gr/dL) Mean \pm SD & $14,62 \pm 1,48$ & $14,51 \pm 1,56$ \\
Pasien yang mengalami anemia n(\%) & $2(11,7)$ & $4(23,5)$ \\
Jumlah eritrosit (x106/Ml) Mean \pm SD & $5,14 \pm 0,5$ & $5,23 \pm 1,02$ \\
MCV (fl) Mean \pm SD & $84,08 \pm 5,37$ & $85,35 \pm 5,88$ \\
MCHC (gr/dL) Mean \pm SD & $33,82 \pm 1,01$ & $34,19 \pm 0,82$ \\
MCH (pg) Mean \pm SD & $28,51 \pm 1,95$ & $28,76 \pm 2,07$ \\
RDW (\%)Mean \pm SD & $13,85 \pm 0,88$ & $13,82 \pm 0,99$ \\
\hline
\end{tabular}

Tabel 2. Hasil uji beda kadar hemoglobin dan parameter eritrosit pada pasien PPOK yang mendapatkan terapi LABACS dan non LABACS.

\begin{tabular}{lccc}
\hline Variabel & LABACS $(\mathrm{n}=17)$ & Non LABACS $(\mathrm{n}=17)$ & $\mathrm{p}$ value \\
\hline Kadar hemoglobin $(\mathrm{g} / \mathrm{dL})$ & 14,62 & 14,51 & 0,83 \\
Jumlah eritrosit $\left(\times 10^{6} / \mathrm{\mu l}\right)$ & 5,14 & 5,23 & 0,73 \\
MCV (fl) & 84,08 & 85,35 & 0,89 \\
MCH (pg) & 28,51 & 28,76 & 0,72 \\
MCHC (gr/dL) & 33,82 & 34,19 & 0,33 \\
RDW (\%) & 13,85 & 13,82 & 0,94 \\
\hline
\end{tabular}




\section{Pembahasan}

Penelitian ini dilakukan untuk mengetahui efek pemberian terapi LABACS pada penderita PPOK populasi D terhadap kadar hemoglobin, jumlah eritrosit, RDW dan indeks eritrosit. Dari Tabel 1 didapatkan rata-rata umur pasien PPOK pada kelompok LABACS dan non LABACS 66,5 tahun dan 65,6 tahun, hal ini sesuai dengan prevalensi PPOK pada GOLD 2017 yang menyatakan paling banyak ditemukan pada umur lebih dari 40 tahun. Hasil uji spirometri menunjukkan FVC pada kelompok LABACS $71,87 \%$ dan pada non LABACS $69,82 \%$, hasil FEV1 pada LABACS $47,01 \%$ dan non LABACS $45,4 \%$. Sementara hasil FEV1/FVC pada kelompok LABACS $51,62 \%$ dan non LABACS $51,12 \%$. Berdasarkan hasil ini dapat dilihat bahwa fungsi paru pada kedua kelompok ini mengalami penurunan dan nilai FEV1/FVC $<70 \%$ sehingga bisa didiagnosis PPOK. Riwayat merokok pada pasien yang mengikuti penelitian ini dapat dlihat dari jumlah rokok per hari pada kelompok LABACS rata-ratanya 16,3 batang/ hari dan pada non LABACS rata-ratanya 19,6 batang/hari. Pack per year pada pasien kelompok LABACS 27,6 pak/tahun, sedangkan kelompok non LABACS 35,6 tahun, yang sesuai dengan faktor risiko PPOK pada GOLD 2017 yaitu riwayat merokok dengan pack per year lebih dari 20 pak/tahun.

Respons inflamasi yang timbul pada pasien PPOK akan menyebabkan produksi sitokin berlebih yang bersifat proinflamasi seperti tumor necrosis factor $\alpha$, IL-6, dan interferon-y sehingga sel darah merah memendek jangka hidupnya, sedangkan kompensasi produksi dari sum-sum tulang tidak mencukupi kebutuhan tubuh akibat supresi produksi hormon eritropoietin.10,11 Pada pasien PPOK juga dapat ditemukan kondisi jumlah sel darah merah dan kadar hemoglobin meningkat karena kompensasi tubuh dengan peningkatan sekresi hormon eritropoietin yang menstimulasi produksi sel darah merah. Menurut penelitian, prevalensi anemia lebih tinggi didapatkan pada pasien derajat II dan III PPOK dibandingkan kenaikan hemoglobin pasien PPOK lainnya. ${ }^{12}$ Pada penelitian ini, belum ditemukan adanya perbedaan reaksi inflamasi yang bermakna bila dilihat dari kadar hemoglobin dan paramater eritrosit. Hal ini bisa dilihat dari jumlah eritrosit dan kadar hemoglobin yang tidak berbeda jauh sehingga menandakan reaksi inflamasi yang tidak berbeda jauh setelah pemberian terapi LABACS maupun non LABACS.

Oleh karena fungsi eritrosit sebagai komponen darah yang mengangkut oksigen di sirkulasi darah, maka eritrosit dipilih sebagai variabel yang dilihat untuk menilai perbaikan setelah pasien diterapi kombinasi LABACS dengan melihat kadar hemoglobin, jumlah eritrosit, nilai indeks eritrosit, dan nilai RDW. Selain itu, menurut penelitian yang dilakukan Mathiass (2005) eritrosit merupakan salah satu target kerusakan dari mediator proinflamasi yang mendasari munculnya gejala-gejala PPOK.10

\section{Kadar Hemoglobin pada Pasien PPOK}

Rata-rata kadar hemoglobin pada kelompok yang mendapat terapi LABACS sebesar 14,6 g/dL, sedangkan non LABACS 14,5 $\mathrm{g} / \mathrm{dL}$. Nilai normal hemoglobin pada laki-laki dewasa adalah 13,5-17,2 g/dL, sehingga keduanya masih termasuk ke dalam kisaran normal. Hasil menunjukkan bahwa pasien yang mendapatkan terapi LABACS ditemukan kecenderungan peningkatan kadar hemoglobin bila dibandingkan dengan kelompok non LABACS, walaupun menurut hasil analisis data perbedaannya tidak bernilai signifikan ( $p$ $=0,832$ ). Dari hasil data penelitian juga ditemukan 2 dari 17 pasien $(11,7 \%)$ dengan anemia pada kelompok LABACS, dan 4 dari 17 pasien $(23,5 \%)$ dari kelompok non LABACS. Persentase anemia pada kelompok yang mendapat LABACS menunjukkan jumlah yang lebih rendah bila dibandingkan dengan kelompok yang tidak mendapat LABACS. 
Hal ini sesuai dengan kerja kortikosteroid sebagai antiinflamasi yang dapat mengurangi mediator inflamasi sehingga hemoglobin kembali meningkat dan jumlah pasien dengan anemia lebih rendah. Menurut John dkk. penurunan hemoglobin diakibatkan oleh mediator proinflamasi yang merusaknya. John dkk. melakukan penelitian untuk mengetahui prevalensi anemia pada pasien PPOK dengan menggunakan sampel 101 orang dan dilakukan tes darah lengkap setelah puasa 12 jam. Hasilnya $13 \%$ terkena anemia dengan disertai resistensi terhadap eritropoietin. ${ }^{10}$ Mekanisme anemia belum diketahui secara pasti, namun terdapat peningkatan kadar IL-6 pada pasien PPOK yang menandakan reaksi inflamasi sistemik meningkat dibanding kelompok normal. Maka, pada penelitian ini diperkirakan reaksi inflamasi lebih rendah pada pasien yang mendapatkan kortikosteroid sehingga kadar hemoglobinnya lebih tinggi dan prevalensi anemianya lebih rendah.

\section{Jumlah Eritrosit dan Indeks Eritrosit pada Pasien PPOK}

Pada pemeriksaan rata-rata jumlah eritrosit pada yang mendapat $L A B A C S$ adalah $5,13 \times 10^{6}$, sedangkan pada non LABACS adalah $5,23 \times 10^{6}(p=0,73)$. Jumlah eritrosit normal pada laki-laki dewasa sekitar $5.200 .000 / \mathrm{mm}^{3}( \pm 300.000)$, pada pasien yang mendapat terapi LABACS dan pada kelompok yang tidak mendapat LABACS kedua rataratanya termasuk ke dalam kisaran normal.

Pemeriksaan indeks eritrosit dibagi lagi menjadi MCV $(p=0,89), \operatorname{MCH}(p=0,72)$, dan MCHC $(p=0,33)$. Rata-rata MCV,MCH, dan MCHC pada pasien yang mendapat LABACS sebesar $84,08 \mathrm{fl}, 28,5 \mathrm{pg}$, dan 33,8 g/dL sedangkan pada pasien non LABACS rataratanya $85,35 \mathrm{fl}, 28,7 \mathrm{pg}$, dan $34,1 \mathrm{~g} / \mathrm{dL}$. Nilai normal MCV adalah 80-96 fl, bila dibandingkan dengan nilai normal maka rata-rata kelompok LABACS dan kelompok non LABACS hasilnya termasuk ke dalam kisaran normal. Selanjutnya nilai normal $\mathrm{MCH}$ yaitu $27-33 \mathrm{pg}$, bila dibandingkan dengan nilai normal maka rata-rata $\mathrm{MCH}$ pada kelompok LABACS dan kelompok non LABACS kedua rata-ratanya masih termasuk kisaran normal.

Nilai normal MCHC pada orang dewasa adalah 33-36 gr/dL, bila dibandingkan dengan rata-rata pada kelompok LABACS dan pada kelompok non LABACS maka rata-ratanya masih dalam range yang normal. Menurut penelitian sebelumnya, pada pasien PPOK ditemukan sebesar $43,75 \%$ pasien yang mengalami makrositosis atau peningkatan MCV. ${ }^{8}$ Hal ini juga diperkuat oleh Tuleta (2017) yang melakukan penelitian untuk mengetahui hubungan PPOK dengan atherosklerosis pada 136 pasien dan dilakukan tes darah lengkap. Hasilnya rata-rata $\mathrm{MCH}$ dan $\mathrm{MCHC}$ pasien PPOK lebih rendah dari kelompok kontrol, sedangkan MCV nilainya hampir sama. Anemia pada PPOK dapat disebabkan oleh gangguan pada ginjal atau defisiensi besi, namun berdasarkan hasil GFR tidak terdapat perbedaan. Jadi disimpulkan bahwa anemia kemungkinan disebabkan defisiensi besi akibat inflamasi sistemik. 13 Dari hasil yang didapatkan pada penelitian ini, maka dapat dikatakan bahwa data indeks eritrosit pada pasien PPOK yang mendapat terapi LABACS menjadi lebih baik bila dibandingkan dengan pasien yang belum mendapat terapi, tetapi tidak berbeda pada pasien yang tidak mendapat terapi LABACS.

\section{Red Blood Cell Distribution Width pada Pasien PPOK}

Pada penilaian $\mathrm{RDW}$ rata-rata pada pasien yang mendapat LABACS sebesar $13,84 \%$, sedangkan pada non LABACS $13,82 \%(p=0,94)$. Bila dibandingkan dengan nilai normal RDW sebesar $11,6-14,6 \%$, maka kedua kelompok rata-ratanya masih dalam sebaran nilai normal. Namun bila dibandingkan antara kelompok LABACS dan non LABACS, nilai RDW cenderung meningkat pada pasien yang mendapatkan LABACS dan menandakan reaksi inflamasi yang tidak jauh berbeda antara dua kelompok. 
Menurut beberapa studi sebelumnya, terdapat hubungan antara kadar RDW yang tinggi dengan peningkatan mortalitas beberapa penyakit termasuk PPOK. RDW juga semakin meningkat nilainya seiring bertambah berat derajat penyakit PPOK. ${ }^{9}$ Bila dibandingkan dengan pasien PPOK yang belum mendapat terapi, maka nilai RDW pasien pada penelitian ini sudah normal namun tidak ditemukan perbedaan yang signifikan antara kelompok LABACS dan non LABACS. Hal ini mungkin disebabkan oleh kelompok non LABACS yang sudah menggunakan terapi short acting beta2 agonist (SABA) dan sudah cukup untuk meningkatkan nilai RDW pada kisaran normal.

Berdasarkan hasil penelitian yang didapatkan, maka terapi kombinasi LABACS tidak mempengaruhi kadar hemoglobin dan eritrosit dengan lebih baik bila dibandingkan dengan terapi lainnya untuk pasien PPOK populasi $C$ dan $D$. Walaupun demikian, masih banyak keterbatasan yang ditemukan pada penelitian ini yaitu jumlah pengambilan data pasien hanya sekali, waktu pengobatan yang singkat, dan faktor risiko lain yang tidak diketahui peneliti.

\section{Kesimpulan}

Kesimpulan yang didapatkan yaitu tidak ada perbedaan kadar hemoglobin dan parameter eritrosit pada pasien yang mendapat dan tidak mendapat terapi LABACS pada pasien PPOK populasi D. Persentase pasien PPOK yang terkena anemia pada kelompok yang mendapat LABACS lebih rendah bila dibandingkan dengan yang tidak mendapat LABACS

\section{Saran}

Perlu dilakukan penelitian dengan pengambilan data secara berkala sebelum dan sesudah pemberian terapi dengan jumlah sampel yang lebih banyak. Perlu dilakukan penelitian pada pasien dengan penggunaan terapi yang lebih lama sehingga hasilnya lebih valid.

\section{Daftar Pustaka}

1. Soeroto AY dan Suryadinata H. Penyakit Paru Obstruktif Kronik. Ina J Chest Crit and Emerg Med. 2014; 1(2):83/

2. Riset Kesehatan Dasar. Litbang Depkes, Jakarta. 2013. HIm. 85.

3. WHO. COPD Predicted to be The Third Leading Cause of Death in 2030. WHO Statistics. 2008.

4. GOLD. Global Strategy for The Diagnosis, Management, and Prevention of Chronic Obstructive Pulmonary Disease. GOLD. $p$. 1-110.

5. Mapel DW, Hurley JS, Roblin D, Roberts M, Davis KJ, Schreiner R, et al. Survival of COPD Patients Using Inhaled Corticosteroids and Long-Acting Beta Agonists. Respiratory Medicine. 2006; 100:595-609.

6. Wiyono WH. Position LABACS in New GOLD Guideline. The 10th Scientific Respiratory Medicine Meeting PIPKRA 2012. Jakarta: Kalbemed. 2012. HIm. 233-234.

7. Khaidir M. Anemia Defisiensi Besi. Jurnal Kesehatan Masyarakat Andalas. 2007. 2 (1):140-144

8. Sarkar M, Rajta PN, Khatana J. Anemia in Chronic Obstructive Pulmonary Disease: Prevalence, Pathogenesis, and Potential Impact. Lung India. 2015; 32:142-149.

9. Tertemiz KC, Alpaydin AO, Sevinc C, Ellidokuz H, Acara AC, Cimrin A. Could "Red Cell Distribution Width" Predict COPD Severity?. Rev Pol Pneumologia. 2015; 22 (4):196-201. http://dx.doi.org/10.1016/ j.rppnen.2015.11.006

10. John M., Hoernig S., Doehner W., Okonko D.D., Witt C., Anker S.D., Anemia and Inflammation in COPD, Chest Journal, $2005 ; \quad 127(3): 825-829$. www.chestjournal.org 
11. El Gazzar AG, Al Mehy GF, Gouda TM, El -Shaer OS, Mohammed SH. Evaluation of Erythropoietin Hormone in Chronic Obstructive Pulmonary Disease Patients during Exacerbation and After Remission. Egyptian Journal of Chest Diseases and Tuberculosis. 2017. 6(1):27-32. http:/l dx.doi.org/10.1016/i.ejcdt.2016.08.015.
12. Tuleta I, Farrag T, Busse L, Pizzaro C, Schaefer $C$, et.al. High Prevalence of COPD in Athelosclerosis Patients. International Journal of COPD. 2017; 12:30473053. http://dx.doi.org/10.2147/ COPD.S141988. 